\title{
So What Is Street Law Anyway - A U.S. Perspective
}

Margaret E. Fisher ${ }^{1}$

\section{Introduction}

This article briefly explores the current problems surrounding young people's knowledge, skills and engagement in the civic life of the democracy in the United States and the contributions that public legal education or civic learning ${ }^{2}$ can make to improving youth engagement as members of a democracy. The article will acknowledge the contribution made by the law-related education movement of the 1950s. More specifically, the article will explore the history of a law school based program - Street Law -- that describes the most important way that law schools in the United States contribute to civic learning. Finally, the article will reveal the actual source of the term "Street Law" and the ongoing impact that Street Law has on the young people and the law students who teach it.

\section{The Problem in the U.S.}

In recent years, study after study has shown that most young people in the United States have poor knowledge of, and are disconnected from, the basics of our democracy. For example, in 2014 only $23 \%$ of $8^{\text {th }}$ graders (13 year olds) in the United States tested

\footnotetext{
${ }^{1}$ Margaret E. Fisher is a Distinguished Practitioner in Residence, Seattle University School of Law, Seattle WA, USA.

${ }^{2}$ I will use the term "civic learning," instead of public-legal education, which is the more common term in Washington State and in many other states in the U.S.
} 
"proficient" on the Nation's Report Card civics exam³. In 2016, only one third of Americans could name the three branches of government and another one third could not even name one branch of government. ${ }^{4}$ This is not important as a test of rote memorization. However, if there is no basic understanding of the role of the branches of government in the lives of Americans, there is no way for citizens to access government and government is no longer in the hands of the people.

There is also less tolerance as the checks and balances work out issues in public life. This leads to more strident objections and incivility as uninformed persons react to the branches of government playing out their roles. For instance, the federal judge who ruled that the President of the United States' first travel ban of 2017 was unconstitutional, received 47,000 pieces of mail; 1,000 of which were death threats. ${ }^{5}$ This reflects a great ignorance of the role of the judicial branch in deciding whether government actions comply with the U.S. Constitution and laws.

\footnotetext{
3 The National Assessment of Educational Progress's National Report Card, https://www.nationsreportcard.gov/hgc 2014/ (2014).

${ }^{4}$ Kathleen Hall Jamieson, Americans' Knowledge of the Branches of Government Is Declining, Annenberg Public Policy Center of the University of Pennsylvania, (September 13, 2016), http://www.annenbergpublicpolicycenter.org/americans-knowledge-of-the-branches-of-government-isdeclining/

${ }^{5}$ Senior U.S. District Judge James L. Robart, Address at U.S. District Court for the Western District of Washington (July 12, 2017).
} 


\section{Importance of Civic Learning}

We know that quality civic learning is the most important factor in determining whether young people will actively participate in their communities as adults. A democracy thrives when its citizens vote, show up for jury duty, engage in public life, join neighborhood groups, are aware of current civic issues, identify and listen to viewpoints other than their own, attend local government meetings, or voice their concerns to lawmakers.

\section{Street Law: The History}

The first national movement for improving civic learning in the United States began in the 1950s in reaction to U.S. Senator Joe McCarthy's rabid anti-communism movement to impose orthodoxy of thought, eliminate critical examination of issues, and maintain rote learning methods of learning and teaching.

In 1952, in reaction to McCarthyism, Dr. Isidore Starr led a movement that introduced the study of controversy in the examination of the U.S. Constitution and Bill of Rights. As important as the content, he insisted is the interactive methods for teaching. This lawrelated movement had many spin-offs, including Street Law ${ }^{6}$.

\footnotetext{
${ }^{6}$ Isidore Starr, Leading a Revolution in Civics, TVW, 2015, https://vimeo.com/146685644. Dr. Starr
} served on the board of the National Street Law Institute in its early years. 
Street Law involves law students teaching practical law classes, using interactive methods, to high school students, prisoners, mentally ill individuals and others.

The program was launched in 1972 at the Georgetown University Law Center. Jason Newman, attorney for the New World Foundation in Washington, DC, obtained funding to offer a first-ever non-advocacy clinic at Georgetown University Law Center. One component of this non-advocacy clinic was the teaching of a practical law class to the inner-city youth of Washington DC.

Jason Newman approached Vincent Reed, Deputy Director of the DC Public Schools, with the proposal. On hearing him out, Vincent Reed responded, “Oh, you mean 'Street Law'." The term was coined.

In organizing his first class, Professor Newman asked for volunteers to work on Street Law. Ed O’Brien, Johnny Barnes, Stephen Glick, and David Wilmot stepped forward. These four law students and Professor Newman worked nights to create the lessons for the first Street Law program.

That first year, the law students taught in teams in two high schools, in four the next year, and by the third year, the program was in all of the DC high schools. At the same time, Professor Newman successfully approached the D.C. City Council to fund a corrections Street Law clinic ${ }^{7}$. This clinic involved law students teaching inmates of the D.C. jail and

\footnotetext{
7 Interview by Margaret Fisher with Professor Jason Newman, Director and Professor of the D.C. Project that included Street Law and Harrison Institute, Georgetown University Law Center (August 19, 2017).
} 
prisons. A later development was including the criminally insane at St. Elizabeth's Hospital.

Upon graduation from law school, Ed O'Brien requested continuing to work on Street Law. He was able to raise funds from the Robert F. Kennedy Foundation for his position and that of Ed McMahon. This resulted in the creation of the National Street Law Institute ${ }^{8}$.

Efforts were then made to expand to other law schools. With help from the Robert Kennedy Foundation, the University of Minnesota Law School was the first law school to join. Other Law Schools came on board ${ }^{9}$, although the idea of clinical education, much less Street Law, was quite controversial with many deans and law faculty.

\section{Impact of Street Law}

Anecdotally, law school professors who teach Street Law know that students who have no prior success in school become greatly engaged in class. Students' impressive performances in the culminating mock trials inspire them to raise their expectations for their own lives. Students learn basic law and how to discuss controversial issues in a civil manner. They learn how to avoid legal problems and how to stand up for themselves

\footnotetext{
${ }^{8}$ Later the name was changed to the Institute for Citizen Education in the Law and later to the current Street Law, Inc. In 1983, the Georgetown University Law Center created a separate faculty position for the director of the Georgetown Street Law Clinic and this led to the eventual separation of National Street Law Institute and the Street Law Clinic.

${ }^{9}$ See directory of registered Law School Street Law programs, http://streetlaw.org/en/Page/858/Directory of Registered Law SchoolBased Street Law Programs.
} 
when they have been wronged. They also learn which government bodies to approach with a problem.

A study ${ }^{10}$ of the Georgetown University Law Center's Street Law program had these main findings of the impact of Street Law on the law students from their perspective as lawyers three to fifteen years after graduating: (1) they had very fond and vivid memories of their experience with Street Law, many describing it is as their finest thing they did in law school; (2) it exposed them to the realities of life faced by people they would not otherwise have interacted with; (3) it helped them be more understanding and compassionate with clients; (4) it helped them explain the law in practical terms to clients and others; and (5) it gave them confidence in speaking publicly.

As someone who has taught Street Law at Georgetown for five years and more than 35 years at the Seattle University School of Law, I can attest to these same impacts on my students and law students. Former law students report that Street Law has helped them take on training roles in law firms, propelled them into volunteering with mock trial and other programs, and for some, caused them to switch their careers and become teachers.

${ }^{10}$ Birnbaum, Marcia, A Case Study of the Georgetown University Law Center Street Law Program, 2000 (unpublished). 